\title{
Biochar for Soil Management: Effect on Soil Available N and Soil Water Storage
}

\author{
Yeboah Edward $^{1}$, Antwi Boasiako Ohene ${ }^{1}$, Ekyem Seth Obosu², Tetteh Francis Marthy ${ }^{1}{ }^{\circ}$ and Bonsu Kwasi Offei ${ }^{2}$ \\ 1. Soil Research Institute, Council for Scientific and Industrial Research, Academy Post Office, Kwadaso, Kumasi, Ghana \\ 2. Crops Research Institute, Council for Scientific and Industrial Research, Kumasi, Ghana
}

Received: March 04, 2011 / Accepted: December 12, 2012 / Published: February 28, 2013.

\begin{abstract}
Soil management technologies for climate change adaptation and mitigation are needed to increase and sustain food production in smallholder agriculture while sequestering inert carbon in the soil. In a field studies at Crops Research Institute, Kwadaso-Kumasi Ghana, a control treatment, five inorganic fertilizer combinations $\left(\mathrm{P}_{30} \mathrm{~K}_{60}, \mathrm{~N}_{60} \mathrm{P}_{30} \mathrm{~K}_{60}, \mathrm{~N}_{120} \mathrm{P}_{30} \mathrm{~K}_{60}, \mathrm{~N}_{180} \mathrm{P}_{30} \mathrm{~K}_{60}\right.$ and $\mathrm{N}_{240} \mathrm{P}_{30} \mathrm{~K}_{60}$ ) and four biochar rates + inorganic fertilizer (2 t/ha Biochar $+\mathrm{N}_{60} \mathrm{P}_{30} \mathrm{~K}_{60}$, $4 \mathrm{t} /$ ha Biochar $+\mathrm{N}_{60} \mathrm{P}_{30} \mathrm{~K}_{60}, 6 \mathrm{t} / \mathrm{ha}$ Biochar + $\mathrm{N}_{60} \mathrm{P}_{30} \mathrm{~K}_{60}$ and $8 \mathrm{t} /$ ha Biochar $+\mathrm{N}_{60} \mathrm{P}_{30} \mathrm{~K}_{60}$ ) were assessed for their effect on soil moisture storage, soil available nitrogen and crop yield. The test crop was okra. Biochar amendments increased soil moisture storage by $14 \%$ relative to sole inorganic fertilizer applications. Biochar + inorganic fertilizer relative to sole inorganic fertilizer increased soil available nitrate concentration by $85 \%$ at 0-15 cm soil depth but decreased soil ammonium-N by $71 \%$. Compared to control, inorganic fertilizer $\left(\mathrm{P}_{30} \mathrm{~K}_{60}\right)$ resulted in more than $100 \%$ increase in okra fresh fruit yield. Addition of $60 \mathrm{~kg} \mathrm{~N} / \mathrm{ha}$ to $\mathrm{P}_{30} \mathrm{~K}_{60}$ caused 23\% decline in okra fresh fruit yield but showed $60 \%$ more okra fresh fruit yield than the control. Inorganic $\mathrm{N}$ rates of $120,180 \mathrm{~kg} \mathrm{~N} / \mathrm{ha}$ and $240 \mathrm{~kg} \mathrm{~N} / \mathrm{ha}$ combined with $\mathrm{P}_{30} \mathrm{~K}_{60}$ however caused a decline of $74 \%$ in okra fresh fruit yield. Biochar + inorganic fertilizer increased okra fresh fruit yield by $100 \%$ compared to sole inorganic fertilizer. Biochar, an inert carbon, combined with inorganic fertilizer has tremendous potential to address food insecurity through soil moisture storage and soil $\mathrm{N}$ availability.
\end{abstract}

Key words: Biochar, climate change adaptation, soil ammonium-N, soil nitrate-N, soil moisture.

\section{Introduction}

In moist tropical environment, sustainable agriculture faces large constraints due to low nutrient contents and accelerated mineralization of soil organic matter [1, 2]. The organic matter is usually mineralized very rapidly and only a small proportion of the applied organic matter is stabilized in the soil in the long term, but successively released to the atmosphere as $\mathrm{CO}_{2}$.

As a consequence, CEC (cation exchange capacity) of the soils which is often low due to their clay mineralogy decreases further. Under such circumstances, the efficiency of applied mineral

Corresponding author: Edward Yeboah, Ph.D., research field: soil biology and fertility expert. E-mail: eyeboah5@hotmail.com. fertilizers is very low when the loss of mobile nutrients such as $\mathrm{NO}_{3}^{-}$or $\mathrm{K}$ from the topsoil is enhanced by rainfall [3, 4]. Therefore, nutrient deficiency is prevalent in many crop production systems in moist tropical environment. Yield increase per unit area, rather than area expansion is becoming more important for food production. This in turn implies that efficient soil management is imperative to guarantee food security.

Applications of mulches, compost, and manures have frequently been shown to increase soil fertility. The addition of these organic resources shapes ecosystem function and influences soil fertility and physical properties such as aggregate stability, water holding capacity and CEC [5]. The quantity of organic residues available for application, however, is limited on smallholder farm. Furthermore, they have alternate 
uses such as feedstock for animals, fuelwood and source of building materials. Additionally, the quality of these organic materials is also low hence their direct contribution to readily available soil nutrient is limited. In addition, many smallholder farmers cannot afford the costs of regular applications of mineral fertilizers.

An alternative is the use of more stabilized compounds such as carbonized materials or their extracts [6]. Investigations have shown that carbonized materials from incomplete combustion of organic materials (biochar, black carbon, charcoal) are responsible for maintaining high levels of SOM (soil organic matter) or moisture and available nutrients in anthropogenic soils of the Brazilian Amazon basin [7, 8]. Traditional charcoal production is one example of biochar produced from wood. It has been reported that charcoal additions have positive effects on soil properties and enhance soil fertility and productivity $[9,10]$. Increased $\mathrm{pH}$, addition of exchangeable bases and enhancement of CEC have shown that added charcoal is not only a soil conditioner, but also acts as a fertilizer. Furthermore, addition of charcoal is reported to improve crop yields [6, 10, 11].

Biochar is a carbon rich material produced from pyrolysis of various materials in the absence of oxygen. Biochar can be produced from any biomass feedstock (wood, rice husk, maize residues, poultry litter, cocoa husk etc.). The use of biochar has been proposed to simultaneously mitigate anthropogenic climate change and as a soil additive to improve soil fertility. Ref. [12] showed that the stability of biochar in soils greatly exceeds that of un-charred organic matter.

Although the charring of organic wastes appears to have been practised in many parts of the world, it has ceased to be a common practise. Population increase, shrinking land availability, diffuse pollution and fossil fuel energy security have provided a new motivation for investigating the function of biochar in soils.

The study is to explore the hypotheses: The addition of biochar to the soil improves soil moisture storage and enhances the supply of nitrogen from the soil to the crop.

\section{Materials and Methods}

\subsection{Site Characteristics}

The field experiment was established in 2009 on a cleared two years fallow site at Crops Research Institute at Kwadaso $\left(6^{\circ} 40^{\prime} \mathrm{N}, 1^{\circ} 40^{\prime} \mathrm{W}\right)$. The soil is developed over residuum from weathered granite and it is classified as Orthi-Ferric Acrisol under the World Reference Base [13].

The experimental site has a bimodal rainfall pattern $(1,200 \mathrm{~mm} / \mathrm{yr})$ with the major season occurring between April and July and the minor season between September and December. The initial soil properties are shown in Table 1.

The chemical properties of the biochar used for the studies are: $\mathrm{pH}$ 1:1 $\mathrm{H}_{2} \mathrm{O}$ 9.5, \%N 0.56, available P (60.0 ppm), available K (2,338.63 ppm), Ca (43.89 cmol $(+) / \mathrm{kg}), \quad \mathrm{Mg} \quad(43.96 \quad \mathrm{cmol}(+) / \mathrm{kg}), \quad \mathrm{Na} \quad(0.73$ cmol(+)/kg), K (32.89 cmol(+)/kg).

\subsection{Land Preparation and Soil Sampling}

The field was hand cleared of biomass and all above ground biomass removed. There was no burning

Table 1 Initial soil characteristics of the study site.

\begin{tabular}{lc}
\hline Soil parameters & \\
\hline $\mathrm{pH}\left(1: 1 \mathrm{H}_{2} \mathrm{O}\right)$ & 5.6 \\
Organic C (\%) & 0.97 \\
Total N (\%) & 0.15 \\
Available P (ppm) & 11.4 \\
Exchangeable $\mathrm{K}(\mathrm{cmol}(+) / \mathrm{kg})$ & 0.25 \\
Exchangeable Ca $(\mathrm{cmol}(+) / \mathrm{kg})$ & 3.23 \\
Exchangeable $\mathrm{Mg}(\mathrm{cmol}(+) / \mathrm{kg})$ & 1.24 \\
Exchangeable $\mathrm{Na}(\mathrm{cmol}(+) / \mathrm{kg})$ & 0.13 \\
Total exchangeable bases $(\mathrm{cmol}(+) / \mathrm{kg})$ & 4.90 \\
Exchangeable acidity & 0.39 \\
Effective cation exchange capacity (cmol(+)/kg) & 5.28 \\
Base saturation $(\%)$ & 92.14 \\
Sand (\%) & 64.01 \\
Silt (\%) & 21.17 \\
Clay (\%) & 14.82 \\
\hline
\end{tabular}


on the field. Soil samples from each experimental unit were taken to a depth of $0-15 \mathrm{~cm}$ for initial soil analyses. Biochar (charcoal), obtained from local charcoal production site in Kumasi, was air dried and sieved through a 2-mm mesh size. The respective weights of biochar application were applied to the soil and incorporated minimally to the soil with a hoe.

To analyse soil available $\mathrm{N}$, soil samples from three depths 0-15 cm, 15-30 cm, 30-45 cm were sampled at 4 weeks after planting. This enabled determination of $\mathrm{N}$ dynamics down the profile. Soil moisture was determined and the values used in the calculation of mineral $\mathrm{N}$ content in the soil. Soil extraction was done by shaking about $20 \mathrm{~g}$ of fresh soil in $125 \mathrm{~mL}$ bottles for $1 \mathrm{~h}$ in $80 \mathrm{~mL}$ of $0.5 \mathrm{M} \mathrm{K}_{2} \mathrm{SO}_{4}$ [14]). The extract was filtered through Whatman paper (No. 42). The filtrate was then analyzed for extractable nitrate [15] and for extractable ammonium using colorimetric method [14].

\subsection{Experimental Design}

The field design was a randomized complete block design with three replicates. The treatments were: (1) Control, (2) $\mathrm{P}_{30} \mathrm{~K}_{60}$, (3) $\mathrm{N}_{60} \mathrm{P}_{30} \mathrm{~K}_{60}$, (4) $\mathrm{N}_{120} \mathrm{P}_{30} \mathrm{~K}_{60}$, (5) $\mathrm{N}_{180} \mathrm{P}_{30} \mathrm{~K}_{60}$, (6) $\mathrm{N}_{240} \mathrm{P}_{30} \mathrm{~K}_{60}$, (7) 2 t/ha Biochar + $\mathrm{N}_{60} \mathrm{P}_{30} \mathrm{~K}_{60}$, (8) $4 \mathrm{t} / \mathrm{ha}$ Biochar $+\mathrm{N}_{60} \mathrm{P}_{30} \mathrm{~K}_{60}$, (9) $6 \mathrm{t} / \mathrm{ha}$ Biochar $+\mathrm{N}_{60} \mathrm{P}_{30} \mathrm{~K}_{60}$, and (10) $8 \mathrm{t} / \mathrm{ha}$ Biochar + $\mathrm{N}_{60} \mathrm{P}_{30} \mathrm{~K}_{60}$. The treatments were in three categories: 1) Control un-amended, i.e., treatment (1); 2) five inorganic fertilizer, i.e., treatments (2) to (6); and 3) four combined biochar and inorganic fertilizer, i.e., treatments (7) to (10). Category 1) was to mimic farmers' practice, Category 2) was to explore the effect of rate of urea application on okra yields while category 3) was to evaluate the effect of quantity of biochar application on okra fresh fruit yield. The plot size was $2.4 \mathrm{~m} \times 2.7 \mathrm{~m}$ with $1.5 \mathrm{~m}$ between blocks and okra was planted at a spacing of $60 \mathrm{~cm} \times 30 \mathrm{~cm}$.

\subsection{Crop Management}

The test crop was okra (Abelmoschus esculentus L.
Moenech), a local landrace obtained from Kpando-Tokor in the Volta Region of Ghana. It was planted on July 24, 2009 at four seeds per hill and thinned to two per stand two weeks after planting. Inorganic $\mathrm{N}$ was applied as urea in split form. A third was applied at planting and two thirds, six weeks after planting.

Phosphorus was applied as triple superphosphate at planting and potassium applied in the form of muriate of potash. All the fertilizers were surface applied and incorporated into the field with a hoe to a depth of 10 $\mathrm{cm}$. The plants were protected against insect pest by weekly spraying of karate insecticide. Three weeding were done before harvest.

At harvest, okra fruits were taken from a net plot area of $1.08 \mathrm{~m}^{2}$. Harvesting was done thrice a week for eight continuous weeks. The total fresh fruit per treatment was obtained by summation of the weekly fresh fruit.

\subsection{Statistical Analyses}

The effects of treatments on okra fresh fruit yield and soil nutrients were determined using GenStat ${ }^{\circledR}$ (2007) and the ANOVA procedure [16]. Means were separated using lsd at $P<0.05$.

\section{Results}

\subsection{Soil Available $N$}

The effect of soil management on the concentration of soil nitrate within the soil profile $(0-30 \mathrm{~cm})$ is shown in Fig. 1. Treatments and soil depth significantly influenced soil nitrate $\mathrm{N}$ concentrations. The control plots, un-amended treatment showed the least soil nitrate $\mathrm{N}$ at $0-15 \mathrm{~cm}$ and $15-30 \mathrm{~cm}$ soil depths. Soil nitrate concentration decreased with depth across treatments, however, significant differences among treatments were observed at $0-15 \mathrm{~cm}$ and 15-30 cm depths. Results clearly demonstrate higher soil nitrate $\mathrm{N}$ contents with biochar application compared with sole inorganic $\mathrm{N}$ application.

Similar to soil nitrate $\mathrm{N}$ concentration, treatments 


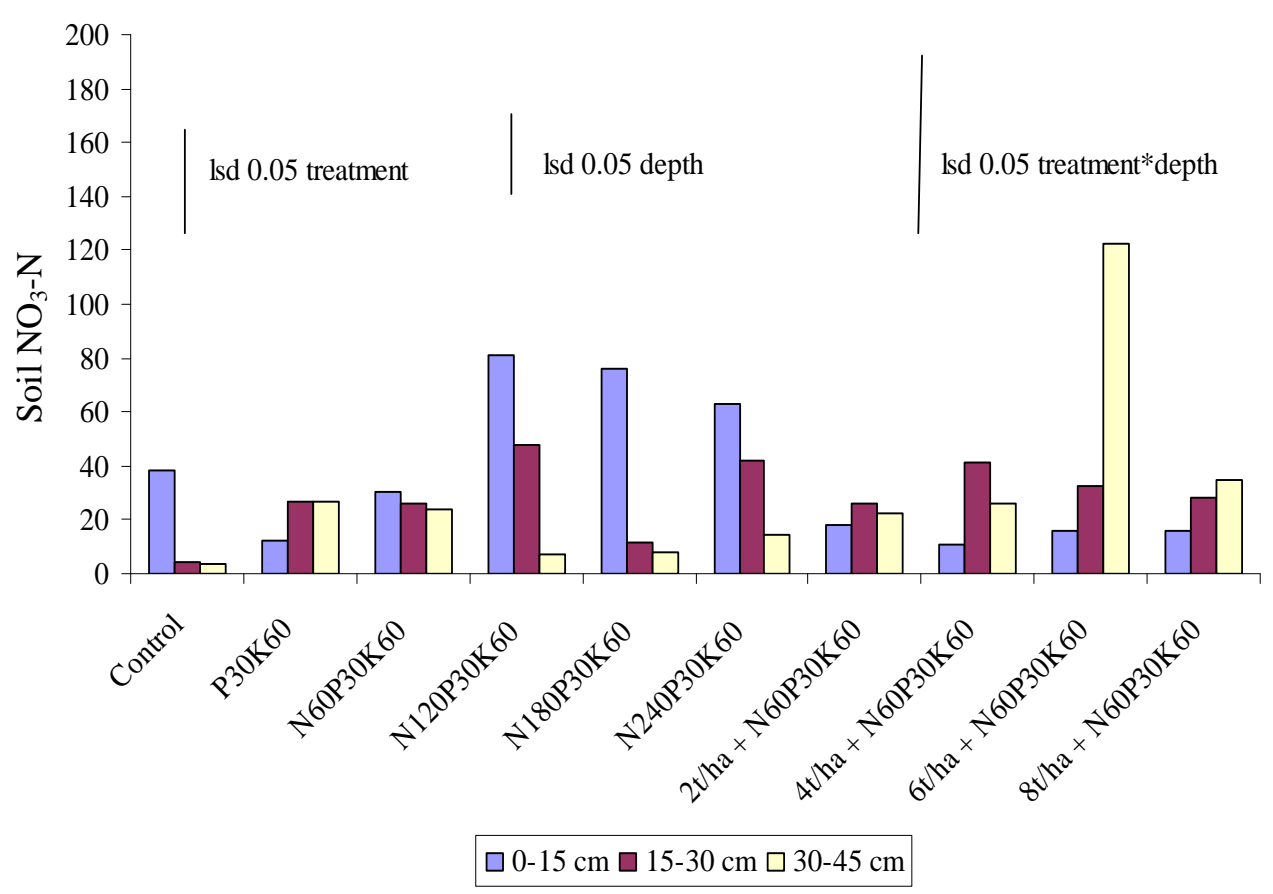

Fig. 1 Effect of soil management on soil nitrate at four weeks after planting okra on an Ultisol at Kwadaso.

and soil depths influenced soil ammonium $\mathrm{N}$ concentration. The control treatment and inorganic $\mathrm{N}$ application resulted in a decline in soil ammonium $\mathrm{N}$ concentration with depth (Fig. 2) but combined application of biochar and inorganic $\mathrm{N}$ showed increase of ammonium concentration with soil depth. Inorganic $\mathrm{N}$ application showed significantly higher ammonium $\mathrm{N}$ concentration at $0-15 \mathrm{~cm}$ soil depth which was significantly higher than combined application of biochar and inorganic $\mathrm{N}$.

\subsection{Soil Moisture}

The influence of soil management practices and depth of sampling on soil moisture at four weeks after planting is shown in Fig. 3. Soil moisture was influenced significantly by the treatments $(P<0.003)$ as well as depth of sampling $(P<0.004)$. Soil moisture increased with depth with the $30-45 \mathrm{~cm}$ depth storing more moisture than the $15-30 \mathrm{~cm}$ which also showed more moisture than the $0-15 \mathrm{~cm}$.

The trend of moisture storage with depth was $30-45 \mathrm{~cm}$ (10.79\%), $15-30 \mathrm{~cm}$ (10.33\%) and 0-15 cm (8.87\%). Soil moisture at depths 30-45 cm and 15-30 $\mathrm{cm}$ were not significantly different from each other but both were significantly higher than the 0-15 cm depth. In general, biochar amendments to soil increased soil moisture relative to inorganic $\mathrm{N}$ application without biochar application. Within the biochar application treatments, $6 \mathrm{t} / \mathrm{ha}$ and $8 \mathrm{t} / \mathrm{ha}$ significantly influenced soil moisture storage compared to $2 \mathrm{t} / \mathrm{ha}$ and $4 \mathrm{t} / \mathrm{ha}$.

\subsection{Okra Fresh Fruit Yield}

Phosphorus and potassium $\left(\mathrm{P}_{30} \mathrm{~K}_{60}\right)$ amendment to the soil resulted in more than $100 \%$ increase in okra fresh fruit yield relative to the control un-amended soil (Fig. 4). Supplementary addition of $60 \mathrm{~kg} \mathrm{~N} / \mathrm{ha}$ to $\mathrm{P}_{30} \mathrm{~K}_{60}$ caused $23 \%$ decline in okra fresh fruit yield but resulted in 60\% more okra fresh fruit yield compared to the control un-amended treatment. Higher application rate of inorganic $\mathrm{N}(120 \mathrm{~kg} \mathrm{~N} / \mathrm{ha}$, $180 \mathrm{~kg} \mathrm{~N} / \mathrm{ha}$ and $240 \mathrm{~kg} \mathrm{~N} / \mathrm{ha}$ ) combined with $\mathrm{P}_{30} \mathrm{~K}_{60}$, however, caused a decline (ranging from $69 \%$ to $78 \%$ ) in okra fresh fruit yield.

Combined application of biochar and inorganic fertilizer, however, showed superior okra fresh fruit 


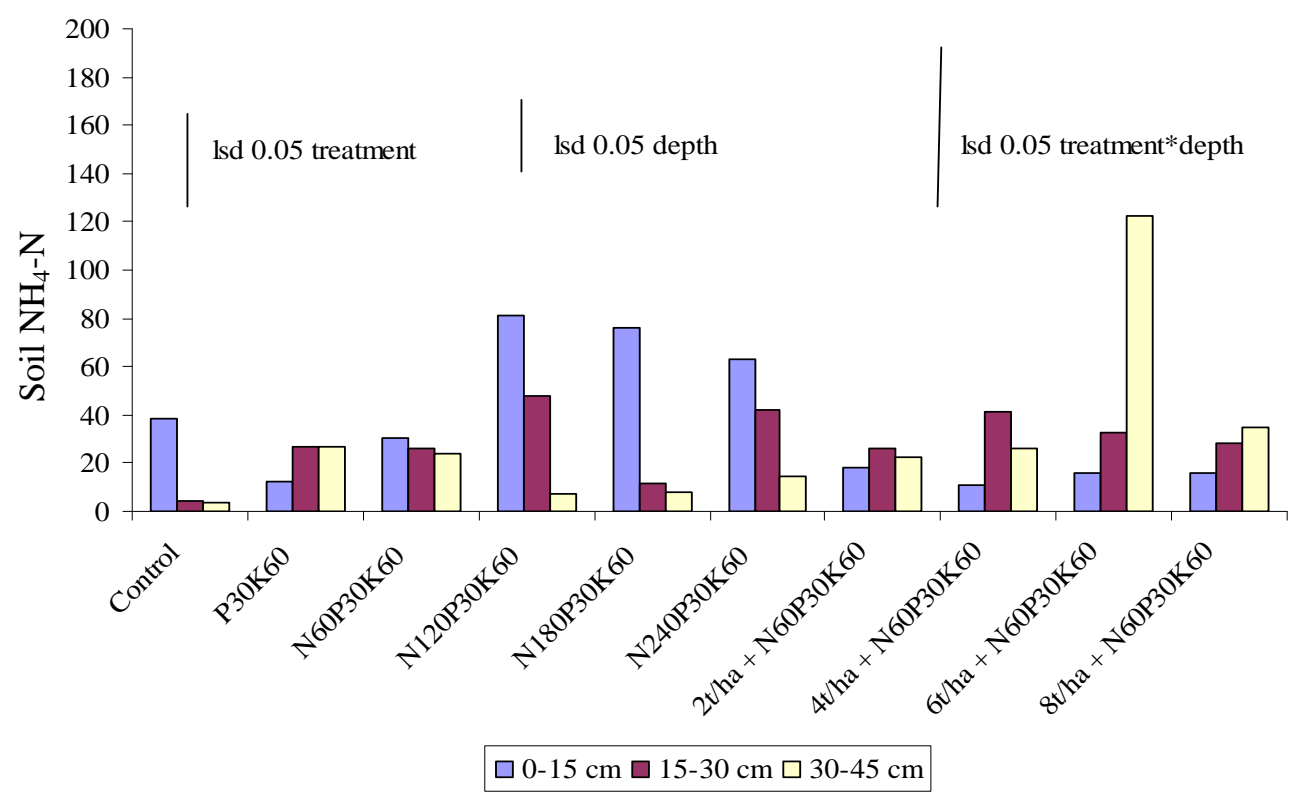

Fig. 2 Effect of soil management on soil ammonium-N at four weeks after planting okra on an Ultisol at Kwadaso.

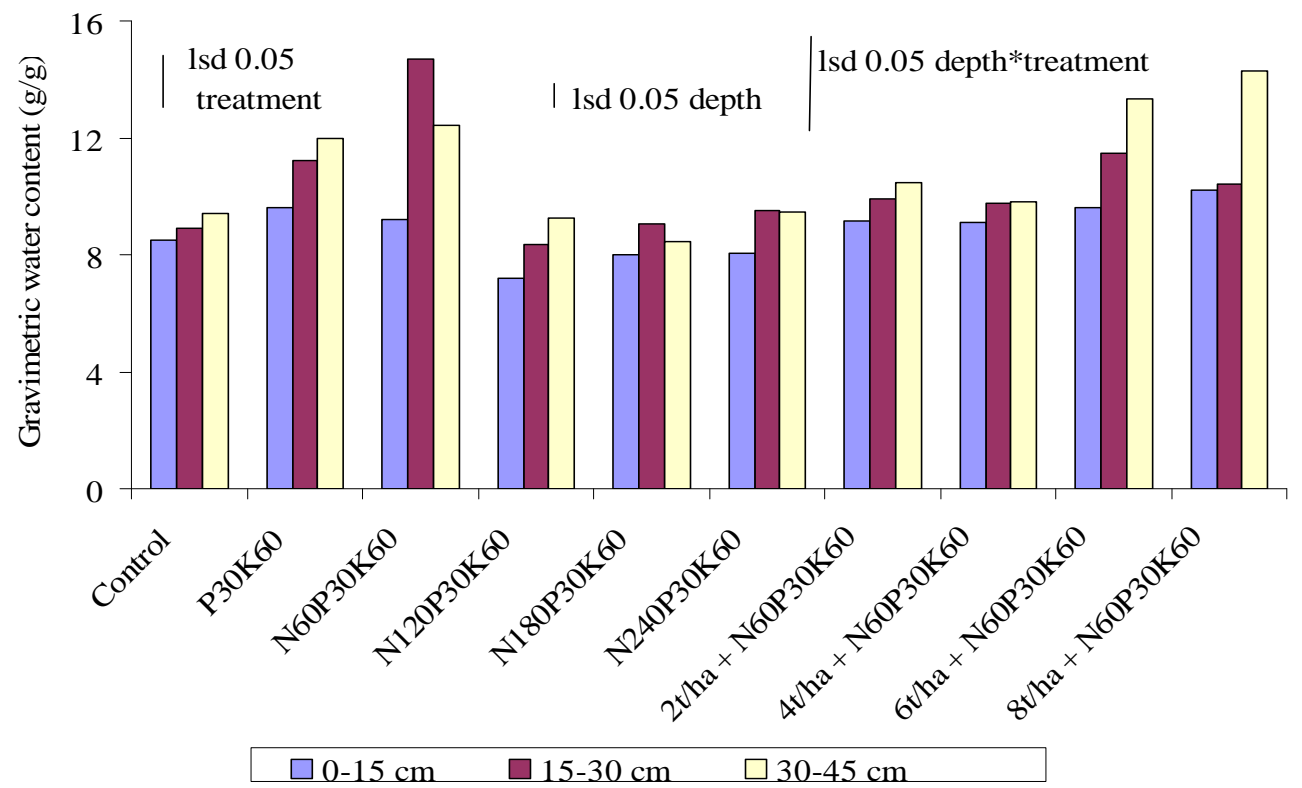

Fig. 3 Changes in soil moisture with depth as influenced by different soil management practices.

yield. The added benefit of biochar amendment to okra fresh fruit yield ranged from $8.6 \%$ to $43 \%$. With the exception of $\mathrm{P}_{30} \mathrm{~K}_{60}$, in general, combined application of biochar and inorganic fertilizers showed higher okra fresh fruit yield compared with inorganic fertilizers. Within the biochar treatments, quantity of application was not significant $(P<0.05)$ but the highest yield of $11.6 \mathrm{t} / \mathrm{ha}$ was obtained from $2 \mathrm{t} / \mathrm{ha}$ biochar $+\mathrm{N}_{60} \mathrm{P}_{30} \mathrm{~K}_{60}$.

\section{Discussion}

\subsection{Soil Available N and Soil Moisture}

The majority of countries in need of increasing food security are located in sub-Saharan Africa. The farmers in most of these countries, particularly in semi-arid areas, have to cope with highly variable and 


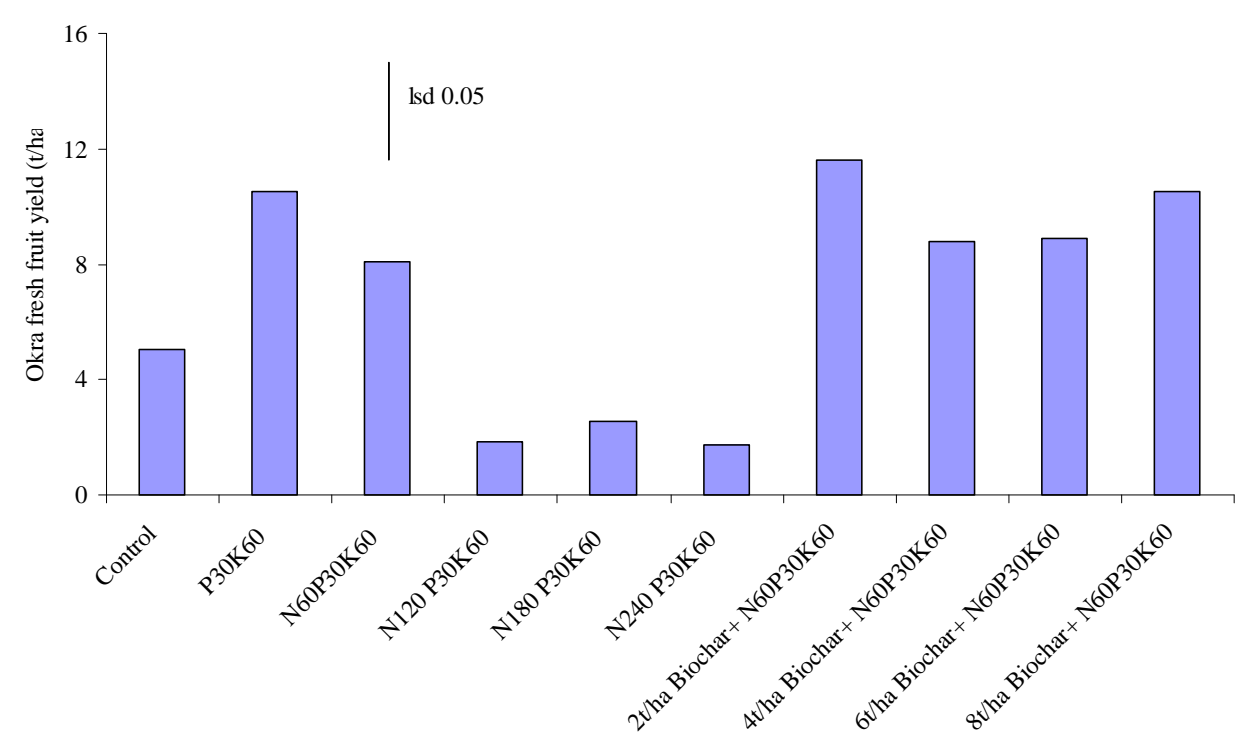

Fig. 4 Effect of soil amendments on okra fresh fruit yield (t/ha) on an Ultisol at Kwadaso, Kumasi, Ghana.

unpredictable rainfall, short rainy seasons, and recurrent drought, all exacerbated by high evaporation rates. Yet, agriculture in these areas is rain-fed.

Nutrient levels are also low and management options to improve soils nutrients and increase crop productivity are urgently needed. These problems have been exacerbated by climate change. Biochar, a product obtained by pyrolysis of wood, has received recognition to address food security, climate change and pollution [17].

The results support the use of biochar to enhance soil $\mathrm{N}$ availability and to improve soil moisture retention for increased plant growth. Considering the fact that a number of feedstuff such as plant residues, sawdust from sawmills are available and are considered as pollutants, these waste materials can be charred and utilised in a beneficial way in agriculture. Incorporation of biochar to the soil is beneficial in trapping water to increase soil moisture retention. Biochar can therefore be used in surface application under conservation tillage to improve soil moisture.

Africa is among the lowest region where fertilizer use in agriculture is limited. The use of mineral fertilizers in sub-Saharan Africa is limited by the lack of purchasing power and scarcity of the product in the smallholder sectors where their continuous use can also lead to a decline in soil organic matter by enhancing its decomposition [18]. The combined application of biochar and inorganic fertilizers has clearly shown improvement in soil available nitrate which decreased with depth. Thus the efficiency of the already limited $\mathrm{N}$ application in smallholder agriculture can be improved tremendously through biochar application. The relatively higher concentration of soil nitrate $\mathrm{N}$ in the top $30 \mathrm{~cm}$ of the soil depth suggests readily available soil $\mathrm{N}$ for plant growth and decreased leaching. Biochar application promoted soil nitrate $\mathrm{N}$ concentration and reduced leaching of the applied soil $\mathrm{N}$.

The relatively higher concentration of soil ammonium-N with depth from the combined biochar and inorganic fertilizer treatments suggest that ammonium-N could be transformed to nitrate- $\mathrm{N}$ for crop uptake at lower depths. Since nitrates leach faster than ammonium, the higher concentration of ammonium at lower depths could be considered stored nutrients for later transformation. This stored nutrient can then be released to synchronize with crop demand.

The improvement of soil moisture storage with biochar application is important for the smallholder 
farmer who has to cope with unreliable rainfall, recurrent drought. The increase in soil moisture with soil depth ensures that soil moisture is not limiting plant growth particularly when crop roots are beyond 0-15 cm. Biochar can therefore be used in the "green water" technology particularly in arid and semi-arid regions of the tropics.

\subsection{Okra Fresh Fruit Yield}

Okra is a widely cultivated vegetable in Ghana and can be found in almost every market all over Africa [19]. Nitrogen as well as phosphorus plays an important role in fruit development of okra. NPK fertilizer has been reported to give a yield increase in okra [19]. Due to the inherently low levels of NPK in tropical soils, it is often imperative to add these nutrients for good yield of most crops including okra.

The decline in okra fresh fruit yield at $\mathrm{N}$ application rate above $60 \mathrm{~kg} / \mathrm{ha}$ is consistent with the findings of Olasantan and Majanbu et al. [20, 21], who recommended $60 \mathrm{~kg} \mathrm{~N} / \mathrm{ha}$ and $50 \mathrm{~kg} \mathrm{~N} / \mathrm{ha}$ for okra respectively. It is expected that as soil moisture decreases particularly during drier periods, quantity of biochar application may be important to increase soil moisture content for okra growth.

The superior okra fresh fruits obtained from combined application of biochar and inorganic fertilizer could be due to higher nitrate availability and retention within the rooting zone of okra as well as improved soil moisture. The effect of biochar in enhancing soil nitrate availability has been reported by several authors $[6,10]$. Consequently, biochar can be used to increase crop yield while reducing the need for some chemical fertilizer inputs. The lack of significant differences in the okra fresh fruit yield following application of different rates of biochar is consistent with findings of Guerena et al. [22], who reported that rate of biochar application did not have significant effect on maize grain and biomass yields. While Guerena et al. [22] did not observe significant differences in maize yield between plot receiving biochar and those not receiving biochar at any of the fertilization rates, results in the present study show added benefit of combined application of biochar and inorganic fertilizers (between 8.6\% and 46\%).

\section{Conclusion}

The practical implication of the present findings is that okra yield produced by the smallholder farmer can be increased substantially through combined application of inorganic fertilizers and biochar. Biochar can be applied as soil amendment for improving okra yields.

The use of biochar at higher application rate of 6 t/ha and 8 t/ha has shown enormous potential to improve soil moisture storage particularly at lower soil depths $(15-45 \mathrm{~cm})$. As soil moisture is one key component affecting agriculture in the tropics particularly in dryland environment, the use of biochar has potential to increase water stored in the soil, in the root zone and is available for plant growth.

Biochar has enormous potential to increase "green water", i.e., water stored in the soil, in the root zone and available for plant growth. Biochar thus has the potential to increase food production despite scarcity of water. Combined application of biochar and inorganic $\mathrm{N}$ revealed higher soil nitrate $\mathrm{N}$ in the soil at soil depth of 0-15 cm and 15-30 cm. Biochar can therefore be used to improve food production through increased soil $\mathrm{N}$ availability and green water.

Biochar improved the efficiency of rainwater for the benefit of smallholder farmers.

Biochar combined with inorganic fertilizers resulted in a decline in soil ammonium $\mathrm{N}$ at the $0-15 \mathrm{~cm}$ soil depth and increased with soil depth but increased soil nitrate $\mathrm{N}$ which decreased with soil depth.

While sole application of inorganic fertilizers resulted in higher soil ammonium $\mathrm{N}$ concentration which decreased with soil depth, combined application of biochar and inorganic fertilizers rather showed lower soil ammonium $\mathrm{N}$ concentration but increased with soil depth. Soil nitrate concentration on 
the other hand decreased with depth across sole inorganic fertilizers and combined application of biochar and inorganic fertilizers. Combined application of biochar and inorganic $\mathrm{N}$ resulted in more soil nitrate $\mathrm{N}$ concentration.

\section{Acknowledgments}

This research was supported by the International Foundation for Science, Stockholm, Sweden and UNU (United Nations University), Tokyo, Japan, through a grant (C-3484-2) to Edward Yeboah. The financial support of Export Marketing and Quality Awareness Project EMQAP is also acknowledged.

\section{References}

[1] H. Tiessen, E. Cuevas, P. Chacon, The role of soil organic matter in sustaining soil fertility, Nature 371 (1994) 783-785.

[2] W. Zech, N. Senesi, G. Guggenberger, K. Kaiser, J. Lehmann, T.M. Miano, et al., Factors controlling humification and mineralization of soil organic matter in the tropics, Geoderma 79 (1997) 117-161.

[3] R.J. Melgar, T.J. Smyth, P.A. Sanchez, M.S. Cravo, Fertilizer nitrogen movement in a central Amzaon Oxixol and Entisol cropped to corn, Fert. Research (1992) 241-252.

[4] M.D. Cahn, D.R. Bouldin, M.S. Cravo, W.T. Bowen, Cation and native leaching in an oxisol of the Brazilian Amzaon, Agron. J. 85 (1993) 334-340.

[5] E. Milne, D.S. Powlson, C.E. Cerri, Soil carbon stocks at regional scales (preface), Agric. Ecosyst. Environ. 122 (2007) 1-2.

[6] J. Lehmann, Bio-energy in the black, Front. Ecol. Environ. 5 (2007) 381-387.

[7] B. Glasser, E. Balashov, L. Haumaier, G. Guggenberger, W. Zech, Black carbon in density fractionations of anthropogenic soils of the Brazilian Amazon region, Organic Geochemistry 31 (2000) 669-678.

[8] B. Glasser, L. Haumaier, G. Guggenberger, W. Zech, The “Terra Pretta” phenomenon:a model for sustainable agriculture in the humid tropics, Naturuissenchaften 88 (2001) 1.

[9] Q.M. Ketterings, J.M. Bigham, Soil color as an indicator of slash-and-burn fire severity and soil fertility in Sumatra, Indonesia, Soil Sci. Soc. Am. Journal. 64 (2000) 1826-1833.
[10] B. Glasser, J. Lehmann, W. Zech, Ameliorating physical and chemical properties of highly weathered soils in the tropics with charcoal-A review, Biol. Fertil. Soils 35 (2002) 219-230.

[11] P.G. Oguntunde, M. Fosu, A.E. Ajayi, N. van de Giesen, Effect of charcoal production on maize yield, chemical properties and texture of soil, Biol Fertil. Soils 39 (2004) 295-299.

[12] J. Lehmann, J. Gaunt, W. Rondon, Biochar sequestration in terrestrial ecosystem-A review, Mitigation and Adaptation Strategies for Global Change 11 (2006) 403-427.

[13] FAO, World reference base for soil resources, FAO Rome, 1998.

[14] ICRAF, Laboratory Methods for Soil and Plant Analysis, Version 1.1, Nairobi, Kenya, 1995.

[15] J.M. Anderson, J.S.L. Ingram, Tropical Soil Biology and Fertility: A Handbook of Methods, CAB International, Wallingford, UK, 1993.

[16] R.W. Payne, S.A. Harding, D.A. Murray, D.M. Soutar, D.B. Baird, S.J. Welham, et al., The Guide to Genstat Release 9, Part 2: Statistics, Oxford: VSN International (2006) p. 1058

[17] S. Sohi, E. Lopez-Capel, E. Krull, R. Bol, Biochar's roles in soil and climate change l: A review of research needs. CSIRO Land and Water Sciences Report 05/09, 2009, pp. 64.

[18] F. Mtambanengwe, P. Mapfumo, Organic matter management as underlying cause for soil fertility gradients on smallholder farms in Zimbabwe, Nutr. Cycling Agroecosyst. 73 (2005) 227-243.

[19] L.A. Babatola, Effect of NPK $15: 15: 15$ on the performance and storage life of okra (Abelmoschus esculentus), in: The Proceedings of the Horticultural Society of Nigeria Conference, Nigeria, 2006, pp. 125-128.

[20] F.O. Olasantan, Nitrogen fertilization of okra (Abelmoschus esculentus) in an intercropping system with cassava (Manihot esculenta) and maize (Zea mays) in south-western Nigeria, The Journal of Agricultural Science 3 (1999) 325-334.

[21] I.S. Majanbu, V.B. Ogunlela, M.K. Ahmed, J.D. Olarewaju, Response of two okra varieties (Abelmoschus esculentus L. Moench) to fertilizer: Yield and yield components as influenced by nitrogen and phosphorus application, Fert. Res. 6 (1984) 257-267

[22] D. Guerena, J. Lehmann, S. Riha, K. Hanley, A. Enders, Biochar Influences on nitrogen leaching and uptake using $15 \mathrm{~N}$ in a maize cropping system in Northeastern USA, An. Mtgs Abstracts, 2009, P. 55846. 